Premiere Educandum: Jurnal Pendidikan Dasar dan Pembelajaran

Volume 11 (2) 280 - 295 December 2021

ISSN: 2088-5350 (Print) / ISSN: 2528-5173 (Online)

Doi: $10.25273 /$ pe.v11i2.9995

The article is published with Open Access at: http://e-journal.unipma.ac.id/index.php/PE

\title{
The contribution of the traditional game of congklak to mathematics learning: How is the relationship and influence of interest, cooperative character and student responses
}

Kamid $\bowtie$, Universitas Jambi

Sofnidar, Universitas Jambi

Sabila Eka Septi, Universitas Jambi

Yulita Dwi Citra, Faculty Universitas Jambi

$\bowtie$ kamid.math@unja.ac.id

\begin{abstract}
This study tested a sample of 70 students with variables of interest, cooperation skills and responses in the math game of congklak from two schools, namely SD IT Aulia and SDN 112/I Perumnas. The objectives of the study: (1) to determine the comparison between interest, cooperative character and student responses in the traditional game of congklak in mathematics. (2) to determine the relationship of interest, cooperation with students' responses to the traditional game of congklak in mathematics. This type of research uses quantitative methods with a comparative type. The instrument in this study used a questionnaire on interests and observation sheets, namely the character of cooperation and student responses to the traditional game of congklak in mathematics. The results of the T-test obtained based on the table can be found that there is a relationship between interest, cooperative character and student responses in the traditional game of Congklak. In the table-based test, it can be said that there is a relationship between interest, cooperative character and student responses to the traditional game of congklak in mathematics
\end{abstract}

Keywords: education, interest, cooperative character, student respon, elementary school

Received 27 July 2021; Accepted 14 October 2021; Published 27 December 2021

Citation: Kamid, K., Sofnidar, S., Septi, S.E., \& Citra, Y.D. (2021). The contribution of the traditional game of congklak to mathematics learning: How is the relationship and influence of interest, cooperative character and student responses. Premiere Educandum : Jurnal Pendidikan Dasar dan Pembelajaran, 11(2), 280 - 295. Doi.org/10.25273/pe.v11i2.9995

\section{(cc) EY-NC-SA}

Published by Universitas PGRI Madiun. This work is licensed under the Creative Commons Attribution-NonCommercialShareAlike 4.0 International License. 


\section{INTRODUCTION}

Education is a right owned by Indonesian citizens. Education is a process that occurs with the aim of developing one's abilities and character (Andriana et al., 2017; Hartini et al., 2018; Afandi et al., 2019). Education is required to be able to improve the quality of a person so that they have high competitive achievements (Yuliyani et al., 2017; Syam, 2019; Kosim, 2020). Education is very important for everyone to form attitudes and selfcharacter (Buldur \& Omeroglu, 2018; Darmaji et al., 2019; Suastra et al., 2017). Through education, there is a process of character formation in every human being.

Children's education in Indonesia generally begins with the elementary school level. Elementary schools occupy an important position in learning (Rapih \& Sutaryadi, 2018; Labudasari \& Rochmah, 2019; Muhardini et al., 2020). The learning process will take place well, if teachers and students have good communication and this learning process can be formed since students are in elementary school (Sappaile, 2017; Rusmono \& Alghazali, 2019; Syahrial et al., 2019). The learning process in elementary schools requires continuous development to improve the quality of learning so that learning objectives can be achieved (Supriadi \& Hignasari, 2019; Utaminingsih et al., 2018; Wahyu et al., 2020). Elementary school is a level of education which is the foundation of knowledge for students.

There are many subjects taught in elementary school, one of which is mathematics. Mathematics is a science that supports the development of students' mindsets as well as a universal science that supports technological development (Rasyid, 2017; Awalia et al., 2019; Purwasi \& Fitriyana, 2019). Mathematics is a subject that has an important role for students (Muslimin. et al., 2017; Noto et al., 2018; Firdaus et al., 2019). Through mathematics lessons, students' creative attitudes and mindsets are formed (Maharani et al., 2013; Nurwahidah et al., 2021; Purwasi \& Fitriyana, 2019). Mathematics lessons provide many benefits and positive impacts on students' lives.

The interest that a person has for something can be called interest. Interest is a desire that can be positive or negative (Oyedeji, 2017; Chetty et al., 2019; Kurniawan et al., 2019). Interest in the context of learning can be interpreted as a driving force for students in achieving learning goals (Setiawan, 2017; Wulandari et al., 2019; Denny et al., 2020). Student interest in learning can be influenced by various factors including teachers (Endayani et al., 2017; Hidayati et al., 2017; Sholihat et al., 2017). Besides the teacher, oneself is the main factor that influences students' interest in learning.

In learning, there is a need for cooperation between each student. Cooperation is an effort made jointly between individuals or groups to achieve common goals (Fauzan et al., 2017; Hetrion et al., 2020; Kosim, 2020). As the school's goal is to create an effective school, a school that has the main characteristics include: strong leadership, high expectations of student achievement, an orderly and comfortable learning environment, on basic skills. In line with educational goals, good cooperation will produce good goals (Amrullah et al., 2017; Labudasari \& Rochmah, 2019; Sunarti et al., 2020). Collaboration can train students' cohesiveness and of course have an impact on maximum learning outcomes (Sunaryo, 2017; Lizawati \& Uli, 2018; Ramdan \& Fauziah, 2019). Cooperation is important for elementary school students to help the learning process.

Learning occurs when there is interaction between teachers and students. Teachers expect feedback that is obtained when learning occurs which is called student response (Ellegaard et al., 2018; Ivanov, 2019; Wood, 2020). Active learning is said to be successful when all students are able to respond during learning (Muir et al., 2020; Newland, 2021; Voith et al., 2018). Some learning in Indonesia is active student participation so that student response becomes very important in learning (Greer \& Heaney, 2004; Karlson, 2019; Lucke et al., 2017). Through this presentation, it can be seen that student responses are very important in learning. 
Research on the character of cooperation, student responses, and interests has been carried out by previous researchers. It's just that the research conducted previously did not discuss the third variable together. This research is in line with research on the character of cooperation that has been carried out by (Amrullah et al., 2017), but in this study did not conduct a correlation test. Other research such as research conducted by (Wood, 2020) which discusses student responses. The study focuses on only one variable in this study, three compared variables. This research is in line with previous research conducted (Febriyanti et al., 2018) on interest. However, previous studies did not discuss the character of cooperation, student responses, and interests together. So that this research is discussed in more detail and with this research it can be seen the comparison and influence between the variables of interest, cooperative character, and student responses to the traditional game of congklak on mathematics subjects.

The urgency in this study is very important because there has been no research that has examined the interest, cooperative character of the traditional congklak game and student responses. In addition, this research also works to see how important students' responses to the cooperative character of traditional games (congklak) are in three elementary schools at once. By looking at how important the character of cooperation is with student responses that conclude from observation, the conclusions are as follows: (1) to find out the relationship between the same interest, cooperative character and student responses in traditional games on subjects (2) to determine the interaction of the interest, character of cooperation with response students in the traditional game of congklak in mathematics.

\section{METHODS}

\section{Design Research}

This design research research uses a quantitative method with a comparative type. Quantitative research is a field of inquiry that stands alone, is scientific in nature and aims to understand social reality (Rukin, 2019). The data obtained using numerical data with a Likers scale 5. This study gains an understanding of the phenomenon from a basic logic, usually covering the study population (Tolley, 2014). Quantitative research which is divided into comparative and using survey procedures. Survey research is a quantitative research procedure wherein administering a survey on a sample or on an entire population design to describe attitudes, opinions, behaviors, or specific characteristics of a population (Creswell, 2012).

\section{Research Instruments}

The instrument in this study used an observation sheet, namely interest, cooperative character, and student responses to the traditional game of congklak in mathematics. There are 6 valid statements on the interest indicator. There are 10 valid statements on the cooperation character indicator. There are 6 valid statements on the student response indicators. This instrument uses a Likert scale. A scale consisting of 5 points with a very good score of 5, good 4, quite 3, not good 2, and not good 1. Each statement represents each indicator of interest, character of cooperation, and student responses. The grid instruments questionnaire of interest in the traditional game of congklak in mathematics is shown in the table 1 . The grid instruments questionnaire of cooperation character in the traditional game of congklak in mathematics is shown in the table 2 . The grid instruments questionnaire of student respon in the traditional game of congklak in mathematics.is shown in the table 3. 
TABLE 1. Grid instruments questionnaire of interest in the traditional game of congklak in mathematics

\begin{tabular}{lll}
\hline No & \multicolumn{1}{c}{ Statements } & \multicolumn{1}{c}{ Indicators } \\
\hline 1 & $\begin{array}{l}\text { I listen well when the teacher is explaining physics subject } \\
\text { matter. }\end{array}$ & \\
2 & $\begin{array}{l}\text { I'm lazy repeatedly learning physics that I get in class when I } \\
\text { get home. }\end{array}$ & Attention in learning \\
3 & $\begin{array}{l}\text { I understand all of the teacher's explanations from start to } \\
\text { finish in the ongoing physics learning process. }\end{array}$ & \\
\hline 4 & $\begin{array}{l}\text { My physics learning material is very, very heavy } \\
5\end{array}$ & $\begin{array}{l}\text { I don't like to give answers if there are questions during the } \\
\text { physics learning process. }\end{array}$ \\
6 & I feel interested in the subject matter being taught. & Student engagement \\
\hline
\end{tabular}

Sources: (Dierks et al., 2016)

TABLE 2. Grid instruments questionnaire of cooperation character in the traditional game of congklak in mathematics

\begin{tabular}{lll}
\hline No & \multicolumn{1}{c}{ Statements } & \multicolumn{1}{c}{ Indicators } \\
\hline 1 & $\begin{array}{l}\text { Children can perform activities that require grouping / sorting } \\
\text { and matching skills. }\end{array}$ & \\
2 & $\begin{array}{l}\text { They pay attention to the object / situation and case. } \\
3\end{array}$ & They can remember what they perceive and learn. \\
4 & Children can carefully observe and examine objects or events. & \\
5 & They can count forward and backward rhythmically. & \\
\hline 6 & They have enough information about the position in space. & \\
7 & Students can do simple addition and subtraction. & Student's ability to learn \\
8 & Students know the symbols used in everyday life. & \\
9 & They can produce solutions to their problems. & \\
& They can establish cause and effect relationships between & \\
\end{tabular}

Sources: (Kazu \& İş, 2018)

TABLE 3. Grid instruments questionnaire of student respon in the traditional game of congklak in mathematics.

\begin{tabular}{llc}
\hline No & \multicolumn{1}{c}{ Statements } & Indicators \\
\hline 1 & Reading material & Student response in \\
2 & Asking questions to the teacher or friends & discussion \\
3 & Express opinions in discussions & Student response in \\
\hline 4 & group or presentation of discussion results & appreciating \\
5 & other people's opinion & \\
6 & Paying attention or listening
\end{tabular}

Sources: (Kusuma \& Aisyah, 2012)

\section{Participant}

The population of this study was 70 students from two schools, namely SD IT Aulia and SDN 112/I Perumnas Jambi City. The sampling technique is total sampling. The subjects taken were each school consisting of 35 students. The sample in this study uses the Probability Sampling sampling technique, which is a sampling technique that provides equal opportunities for each member (element) of the population to be selected as a sample member (Achdiyat \& Utomo, 2018). The reason for using purposive sampling technique is because not all samples have criteria that are in accordance with the phenomenon under study. Therefore, the authors choose a purposive sampling technique which establishes certain considerations or criteria that must be met by the sample used in this study. The number of samples that will be used in this study are students of SD IT 
Aulia and SDN 112/I Perumnas Jambi City. In detail the details of this can be seen in the following table 4.

TABLE 4. Participant detail

\begin{tabular}{cccc}
\hline School & Gender & Total & Mean Age \\
\hline SD IT Aulia & Male & 10 & $10-11$ years \\
& Female & 25 & \\
SDN 112/I Perumnas & Male & 16 & $10-11$ years \\
& Female & 19 & \\
\hline
\end{tabular}

\section{Data analysis technique}

The data analysis technique used is sampling. The sampling technique was adopted because it provides unbiased parameter estimates and is better if the population is homogeneous (Alsabahi et al., 2021). Using sampling can reduce the potential for bias in the selection of cases for inclusion in the sample. Due to the homogeneity of the population, the sampling frame is clear and general in nature. This research was carried out starting from distributing observation sheets, then analyzing quantitative data, then identifying the results for follow-up. At the data collection stage, questionnaires were given to 70 students at SD IT Aulia and SDN 112/I Perumnas. Based on the research objectives of the data, data analysis was carried out, namely data coding, appropriate data filtering and data analysis. that. In describing the data in the form of interest, cooperative character and student responses, the statistics used are descriptive and inverential statistics. Then the data were analyzed using SPSS 26 program to get the percentage, frequency, mean and standard deviation. With this random sampling condition, data deviation is carried out. descriptive statistical test to see the percentage of excellence between two schools in each indicator and variable. Inverential in the form of testing assumptions and hypotheses. Assumption tests in the form of normality and linearity tests were carried out to determine whether the data were categorized as normal and linear. Furthermore, hypothesis testing in the form of $\mathrm{T}$ test and correlation test. The t-test was used based on the research objectives to determine the comparison of interests, character of cooperation and student responses. Correlation test is used based on research objectives to determine the effect of interest, character of cooperation and student responses.

\section{Research procedure}

In collecting data, the first activity that must be done is to select students based on the given categories, then provide interest questionnaires and observation sheets for the character of cooperation and student responses to the traditional game of congklak in mathematics. Then the questionnaire data was processed using the SPSS application. The use of the SPSS application works to see descriptive statistics in the form of mean, min, max, percentage, and category of students. The data needed in research can be collected or obtained from various data sources. then after testing the results obtained and the conclusions obtained.

\section{RESULTS}

The following describes the results of descriptive statistics on variables of interest, cooperative character and student responses. With questions about indicators of interest: Student skills in learning and Student's ability to learn. Indicator statements about cooperative character: student skills in learning indicator and Student's ability to learn Indicators of student response questions: Student response in discussion and Student response in appreciating. Where are the results obtained from distributing questionnaires 
to SD IT Aulia and SDN 112/I Perumnas. The description of students' interest in science on indicators of Attention in learning is shown in the following table.

TABLE 5. Description of students' interest on attention in learning indicator

\begin{tabular}{ccccccccc}
\hline School & Category & Interval & F & $\%$ & Mean & Med & Min & Max \\
\hline & Very not good & $3.0-5.4$ & 0 & 0 & & & & \\
SD IT & Not good & $5.5-7.8$ & 2 & 5.8 & & & & 5.0 \\
Aulia & Enough & $7.9-10.2$ & 21 & 60 & 3.3 & 3.0 & 2.0 & \\
& Good & $10.3-12.6$ & 11 & 31.3 & & & & \\
& Very good & 12.7 .15 .0 & 1 & 2.9 & & & & \\
SDN & Very not good & $3.0-5.4$ & 0 & 0 & & & \\
$112 /$ I & Not good & $5.5-7.8$ & 1 & 2.9 & & & \\
Perumnas & Enough & $7.9-10.2$ & 17 & 48.1 & 3.4 & 3.0 & & \\
& Good & $10.3-12.6$ & 16 & 46.1 & & & & \\
\hline
\end{tabular}

From the description of the table above, it can be seen that the comparison with the enough category in SD IT Aulia is higher than the proportion of SDN 112/I Perumnas so that it can be said that SD IT Aulia is superior to SDN 112/I Perumnas in the indicator of Attention in learning. The description of students' interest in science on indicators of Student engagement is shown in the following table.

TABLE 6. Description of students' interest on student engagement indicator

\begin{tabular}{|c|c|c|c|c|c|c|c|c|}
\hline School & Category & Interval & $\mathrm{F}$ & $\%$ & Mean & Med & Min & Max \\
\hline \multirow{5}{*}{$\begin{array}{l}\text { SD IT } \\
\text { Aulia }\end{array}$} & Very not good & $3.0-5.4$ & 0 & 0 & \multirow{5}{*}{3.4} & \multirow{5}{*}{3.0} & \multirow{5}{*}{2.0} & \multirow{5}{*}{5.0} \\
\hline & Not good & $5.5-7.8$ & 1 & 2.9 & & & & \\
\hline & Enough & 7.9-10.2 & 19 & 53.2 & & & & \\
\hline & Good & $10.3-12.6$ & 10 & 29 & & & & \\
\hline & Very good & 12.7.15.0 & 5 & 14.9 & & & & \\
\hline \multirow{5}{*}{$\begin{array}{c}\text { SDN } \\
112 / \mathrm{I} \\
\text { Perumnas }\end{array}$} & Very not good & $3.0-5.4$ & 0 & 0 & \multirow{5}{*}{3.8} & \multirow{5}{*}{4.0} & \multirow{5}{*}{2.0} & \multirow{5}{*}{5.0} \\
\hline & Not good & $5.5-7.8$ & 2 & 5.8 & & & & \\
\hline & Enough & 7.9-10.2 & 20 & 58 & & & & \\
\hline & Good & $10.3-12.6$ & 10 & 29 & & & & \\
\hline & Very good & 12.7.15.0 & 3 & 8.2 & & & & \\
\hline
\end{tabular}

From the description of the table above, it can be seen that the comparison with the enough category in SDN 112/I Perumnas is higher than the proportion of SD IT Aulia so that it can be said that SDN 112/I Perumnas is superior to SD IT Aulia in the indicator of Student engagement. The description of students' character cooperation on student skills in learning indicator is shown in the following table.

TABLE 7. Description of students' character cooperation on student skills in learning indicator

\begin{tabular}{ccccccccc}
\hline School & Category & Interval & $\mathrm{F}$ & $\%$ & Mean & Med & Min & Max \\
\hline & Very not good & $5.0-9.0$ & 0 & 0 & & & & \\
SD IT & Not good & $10.0-13.0$ & 1 & 2.9 & & & \\
Aulia & Enough & $14.0-17.0$ & 13 & 37.1 & 3.7 & 4.0 & 2.0 & 5.0 \\
& Good & $18.0-21.0$ & 16 & 45.7 & & & & \\
& Very good & $22.0-25.0$ & 5 & 14.3 & & & & \\
SDN & Very not good & $5.0-9.0$ & 0 & 0 & & & \\
$112 /$ I & Not good & $10.0-13.0$ & 1 & 2.9 & & \multirow{2}{*}{3.0} & & \\
Perumnas & Enough & $14.0-17.0$ & 18 & 51.4 & 3.5 & & & \\
& Good & $18.0-21.0$ & 13 & 37.1 & & & & \\
& Very good & $22.0-25.0$ & 3 & 8.6 & & & &
\end{tabular}


From the description of the table above, it can be seen that the comparison with the good category in SDN 112/I Perumnas is higher than the proportion of SD IT Aulia so that it can be said that SDN 112/I Perumnas is superior to SD IT Aulia in the indicator of Student engagement. The description of students' character cooperation on student's ability to learn indicator is shown in the following table.

TABLE 8. Description of students' character cooperation on student's ability to learn indicator

\begin{tabular}{ccccccccc}
\hline School & Category & Interval & F & $\%$ & Mean & Med & Min & Max \\
\hline & Very not good & $5.0-9.0$ & 0 & 0 & & & & \\
SD IT & Not good & $10.0-13.0$ & 2 & 5.8 & & & & \\
Aulia & Enough & $14.0-17.0$ & 20 & 58 & 3.8 & 4.0 & 2.0 & \\
& Good & $18.0-21.0$ & 10 & 29 & & & & \\
& Very good & $22.0-25.0$ & 3 & 8.2 & & & & \\
SDN & Very not good & $5.0-9.0$ & 0 & 0 & & & \\
$112 /$ I & Not good & $10.0-13.0$ & 0 & 0 & & 3.0 \\
Perumnas & Enough & $14.0-17.0$ & 22 & 63.8 & 3.4 & 3.0 & & \\
& Good & $18.0-21.0$ & 9 & 26.1 & & & & \\
\hline
\end{tabular}

From the description of the table above, it can be seen that the comparison with the enough category in SDN 112/I Perumnas is higher than the proportion of SD IT Aulia so that it can be said that SDN 112/I Perumnas is superior to SD IT Aulia in the indicator of Student's ability to learn. The description of students' respon on student response in discussion indicator is shown in the following table.

TABLE 9. Description of students' respon on student response in discussion indicator

\begin{tabular}{ccccccccc}
\hline School & Category & Interval & F & $\%$ & Mean & Med & Min & Max \\
\hline & Very not good & $3.0-5.4$ & 0 & 0 & & & & \\
SD IT & Not good & $5.5-7.8$ & 1 & 2.9 & & & & 5.0 \\
Aulia & Enough & $7.9-10.2$ & 18 & 51.4 & 3.5 & 3.0 & 2.0 & \\
& Good & $10.3-12.6$ & 13 & 37.1 & & & & \\
& Very good & 12.7 .15 .0 & 3 & 8.6 & & & & \\
SDN & Very not good & $3.0-5.4$ & 0 & 0 & & & \\
$112 /$ I & Not good & $5.5-7.8$ & 2 & 5.8 & & \multirow{2}{*}{3.0} & & \\
Perumnas & Enough & $7.9-10.2$ & 21 & 60 & 3.3 & 3.0 & & \\
& Good & $10.3-12.6$ & 11 & 31.3 & & & & \\
\hline
\end{tabular}

TABLE 10. Description of students' respon on student response in appreciating indicator

\begin{tabular}{ccccccccc}
\hline School & Category & Interval & F & $\%$ & Mean & Med & Min & Max \\
\hline & Very not good & $3.0-5.4$ & 0 & 0 & & & & \\
SD IT & Not good & $5.5-7.8$ & 2 & 5.8 & & & & \\
Aulia & Enough & $7.9-10.2$ & 20 & 58 & 3.8 & 4.0 & 2.0 & \\
& Good & $10.3-12.6$ & 10 & 29 & & & & \\
& Very good & 12.7 .15 .0 & 3 & 8.2 & & & & \\
SDN & Very not good & $3.0-5.4$ & 0 & 0 & & & \\
$112 /$ I & Not good & $5.5-7.8$ & 0 & 0 & & \multirow{2}{*}{3.0} & & \\
Perumnas & Enough & $7.9-10.2$ & 22 & 63.8 & 3.4 & & & \\
& Good & $10.3-12.6$ & 9 & 26.1 & & & & \\
\hline
\end{tabular}

From the description of the table above, it can be seen that the comparison with the enough category in SDN 112/I Perumnas is higher than the proportion of SD IT Aulia so 
that it can be said that SDN 112/I Perumnas is superior to SD IT Aulia in the indicator of student response in discussion. The description of students' respon on student response in appreciating indicator is shown in the following table.

From the description of the table above, it can be seen that the comparison with the enough category in SDN 112/I Perumnas is higher than the proportion of SD IT Aulia so that it can be said that SDN 112/I Perumnas is superior to SD IT Aulia in the indicator of student response in appreciating.

\section{Normality test}

The data is normally distributed as seen from the significance value, if the significance value is $>0.05$. The results of the normality test are shown in table below:

TABLE 11. Normality test of interest, cooperation character, and student respon

\begin{tabular}{clccc}
\hline \multirow{2}{*}{ Variable } & \multicolumn{1}{c}{ School } & \multicolumn{3}{c}{ Kolmogorov-Smirnov } \\
\cline { 3 - 5 } & & Statistic & Df & Sig. \\
\hline \multirow{2}{*}{ Interest } & SD IT Aulia & .053 & 35 & $.200^{*}$ \\
& SDN 112/I Perumnas & .123 & 35 & .200 \\
\hline \multirow{2}{*}{ Cooperation character } & SD IT Aulia & .092 & 35 & .200 \\
& SDN 112/I Perumnas & .090 & 35 & $.200^{*}$ \\
\hline \multirow{2}{*}{ Student respon } & SD IT Aulia & .093 & 35 & .200 \\
& SDN 112/I Perumnas & .095 & 35 & $.200^{*}$ \\
\hline
\end{tabular}

Based on the results of table 11 . It can be obtained that the data is normally distributed, the normality test is obtained with the Kolmogorov-Smoniv test, the significance value is > 0.05 .

\section{Linearity Test}

This test is carried out in order to see a linear relationship between two or more variables. The conditions in this test, if the significance value is $<0.05$. The results obtained are shown in table below:

TABLE 12. Linearity test of interest, cooperation character, and student respon

\begin{tabular}{lll}
\hline Variable & School & Sig. \\
\hline Interest $*$ Cooperation character & SD IT Aulia & .043 \\
\cline { 2 - 3 } & SDN 112/I Perumnas & .025 \\
\cline { 2 - 3 } Cooperation character * Student respon & SD IT Aulia & .047 \\
\cline { 2 - 3 } & SDN 112/I Perumnas & .024 \\
\cline { 2 - 3 } Student respon * interest & SD IT Aulia & .045 \\
\cline { 2 - 3 } & SDN 112/I Perumnas & .022 \\
\hline
\end{tabular}

Based on table 12, it can be said that there is a linear relationship between interest, cooperation character, and student responin grades SD IT Aulia and SDN 112/I Perumnas, the results of the linearity test obtained are the significance value has met the requirements $<0.05$.

\section{Hypothesis Test (T test)}

In this test, it is carried out in order to find out the difference between the variables. The condition in this test is if the significance value is $>0.05$, it can be said that the variable has no difference. If the significance value is $<0.05$, then the variable has a significant difference. The results obtained are shown in the following table. 
The T-test of student attitude in grades SD IT Aulia and SDN 112/I Perumnas is described in the following table:

TABLE 13. T-test of student interest, cooperation character, and student respon

\begin{tabular}{cccc}
\hline \multicolumn{1}{c}{ School } & Variable & N & Sig. (2-tailed) \\
\hline \multirow{3}{*}{ SD IT Aulia } & Interest & 35 & 0.044 \\
\cline { 2 - 4 } & cooperation character & 35 & 0.043 \\
\cline { 2 - 4 } & Attitude & 35 & 0.045 \\
\hline \multirow{2}{*}{ SDN 112/I } & Interest & 35 & 0.036 \\
\cline { 2 - 4 } Perumnas & cooperation character & 35 & 0.034 \\
\cline { 2 - 4 } & student respon & 35 & 0.033 \\
\hline
\end{tabular}

From table 13, it is found that there are differences in the interest, cooperation character, and student respon of grades SD IT Aulia and SDN 112/I Perumnas. This is evidenced by the value of sig $(2$-tailed $)<0.05$.

\section{Correlation Test}

In this test, it is carried out in order to determine the relationship of the variable. The correlation test is where a correlation is carried out to determine the relationship between two variables, so that there are no dependent variables and independent variables ( $\mathrm{Li}$ et al., 2021). The condition in this test is if the significance value is $>0.05$, it can be said that the variable has no relationship. If the significance value is $<0.05$, then the variable has a significant relationship. The results obtained are shown in the following table. The correlation test of students' interest, cooperation character, and student respon SD IT Aulia and SDN 112/I Perumnas is described in the following table:

TABLE 14. Correlation test of student interest, cooperation character, and student respon grades $S D$ IT Aulia and SDN 112/I Perumnas

\begin{tabular}{llll}
\hline Variable & N & Pearson Correlation & Sig. (2-tailed) \\
\hline Interest & 35 & 0.645 & 0.028 \\
Cooperation character & 35 & 0.534 & 0.025 \\
Students respon & 35 & 0.436 & 0.022 \\
\hline
\end{tabular}

From table 14, it is found that there is a positive relationship interest, cooperation character, and student respon of SD IT Aulia and SDN 112/I Perumnas with science subjects. This is proven by the value of sig $(2$-tailed $)<0.05$.

\section{DISCUSSION}

The research on the results of the descriptive statistical test is in line with the research conducted by (Ningsi, 2020) which tested the descriptive test, but in this study only used one indicator, namely social implications, while in this study the descriptive results were tested on three variables, namely interest, cooperative character. and student responses with each variable there are two indicators. In this study, there are two indicators of interest variables, namely student learning skills and student learning abilities. Based on the results of table 4, it is known that the comparison with the sufficient category at SD IT Aulia is higher than the proportion of SDN 112/I Perumnas so that it can be said that SD IT Aulia is superior to SDN 112/I Perumnas in the Attention indicator in learning. Based on table 5 , the results show that the comparison with the sufficient category at Perumnas 
SDN 112/I is higher than the proportion of SD IT Aulia so it can be said that SDN 112/I Perumnas is superior to SD IT Aulia in indicators of student involvement.

Research on cooperative character variables is in line with research conducted by (Lacksana, 2017) on local wisdom of the game of congklak as a strengthening of student character, but in this study there were not many variables compared to those in this study. In this study, there are two indicators of cooperative character variables, namely indicators of student learning skills and indicators of student learning abilities. Where based on the results of table 6 the comparison with both categories at SDN 112/I Perumnas is higher than the proportion of SD IT Aulia so it can be said that SDN 112/I Perumnas is superior to SD IT Aulia in indicators of student involvement. Based on table 7, it is known that the comparison with the sufficient category at Perumnas SDN 112/I is higher than the proportion of SD IT Aulia so it can be said that SDN 112/I Perumnas is superior to SD IT Aulia on indicators of students' ability to learn.

This research on student response variables is in line with research conducted by (Nataliya, 2017)on the effectiveness of using the traditional game congklak learning media, but in this study did not conduct several complete tests as was done in this study. In this study, there were two indicators of student response variables, namely student responses in discussing and student responses in appreciating. Where based on the results of table 8, it is found that the comparison of sufficient categories at Perumnas SDN 112/I is higher than the proportion of SD IT Aulia so it can be said that SDN 112/I Perumnas is superior to SD IT Aulia in indicators of student responses in the discussion. Based on table 9 the results obtained are comparisons with the sufficient category at Perumnas SDN 112/I which are higher than the proportion of SD IT Aulia so it can be said that SDN 112/I Perumnas is superior to SD IT Aulia in indicators of student response in respect.

The next test is the assumption test, namely normality and linearity tests. The first hypothesis test is the normality test. The normality test to determine whether the data is normally distributed or not uses Kolmogorov Smirnov by comparing the probability value with a significance value of 0.05 (Psaradakis \& Vávra, 2020). Based on table 10, the significance value of the interest variable at SD IT Aulia is 0.053 and SDN 112/I Perumnas is 0.123 . the variable character of cooperation at SD IT Aulia is 0.092 and SDN 112/I Perumnas is 0.090. Student response variables at SD IT Aulia are 0.093 and SDN 112/I Perumnas is 0.095 . All results on normality are $>0.05$, meaning that the data is normally distributed, the normality test is obtained by the Kolmogorov-Smoniv test. The next test is the linearity test for the calculation of the linearity test in the study using the Anova test with the help of the SPSS version 26 program with the criteria if the linearity sig $<0.05$ then the data has a linear pattern (Astuti, 2017) based on table 11 values The significance of the interest variable at SD IT Aulia is 0.043 and SDN 112/I Perumnas is 0.025. the variable character of cooperation at SD IT Aulia is 0.047 and SDN 112/I Perumnas is 0.024. Student response variables at SD IT Aulia are 0.045 and SDN 112/I Perumnas is 0.022. All results on normality are $>0.05$, which means the data is linearly distributed.

Furthermore, the hypothesis test is the $\mathrm{T}$ test and the correlation test. The first hypothesis test is the T test. This test was conducted to determine the differences between variables. The condition in this test is that if the significance value is $>0.05$, it can be said that the variable has no difference. If the significance value $<0.05$, then the variable has a significant difference. So it can be said that there are differences in the interests, character of cooperation, and responses of the students of SD IT Aulia and SDN 112/I Perumnas. This is evidenced by the value of sig (2-tailed) $<0.05$. Based on table 12 the significance value of the variable of interest at SD IT Aulia is 0.044 and SDN 112/I Perumnas is 0.043 . the variable character of cooperation at SD IT Aulia is 0.045 and SDN 112/I Perumnas is 0.036. Student response variables at SD IT Aulia are 0.034 and SDN 112/I Perumnas is 0.033 . The second test, namely the correlation test, is where the correlation is carried out to determine the relationship between two variables, so that there is no dependent variable and independent variable (Li et al., 2021) based on table 13 the significance value of the variable is 0.028 , the character of the cooperative variable is 0.025 and on the 
student response variable that is 0.022 . So it can be said that there is a positive relationship between interest, cooperative character, and student response at SD IT Aulia and SDN 112/I Perumnas with science subjects. This is evidenced by the value of sig (2tailed) $<0.05$.

The generalization and novelty of this research is to find out the comparison and relationship between the variables of interest, cooperative character and student responses to the game of congklak on mathematics subjects. Where there is no research that examines three variables, namely interest, cooperative character and student responses in two elementary schools at once. So that with this research can be known in more detail about the tests carried out in this study. The traditional game of congklak can be implemented in mathematics because by playing congklak students can practice counting skills and can also grow the character of student cooperation (Akben, 2019).

\section{CONCLUSION}

Based on the results of testing and data analysis, it was found that with a sample of students' interests, cooperation skills and responses in the traditional game of Congklak in mathematics, there were 70 students from two schools, namely SD IT Aulia and SDN 112/I Perumnas with 35 students each. The results of the T-test obtained based on the table can be said that there is a comparison between the variables of interest, cooperative character and student responses to the traditional game of congklak in mathematics subjects at SD IT Aulia and SDN 112/I Perumnas. It is proved that the results of Sig. (2-tails) $<0.05$. The results of the correlation test showed that sig $<0.05$ and it can be said that there is a relationship between the variables of interest, cooperative character, and student responses to the traditional game of congklak in mathematics subjects at SD IT Aulia and SDN 112/I Perumnas. The limitation of this study is that it only measures the variables of interest, cooperative skills and student responses in the traditional game of Congklak Mathematics, but has not been tested with other variables such as learning models and motivation. The suggestion from the researcher is that the researcher recommends conducting further research to compare interest, cooperative character and student responses with other variables such as achievement results and suggesting to conduct research at the elementary school level.

\section{REFERENCES}

1. Achdiyat, M., \& Utomo, R. (2018). Kecerdasan Visual-Spasial, Kemampuan Numerik, dan Prestasi Belajar Matematika. Formatif: Jurnal Ilmiah Pendidikan MIPA, 7(3), 234245. https://doi.org/10.30998/formatif.v7i3.2234

2. Afandi, Sajidan, Akhyar, M., \& Suryani, N. (2019). Development frameworks of the Indonesian partnership 21 st -century skills standards for prospective science teachers: A Delphi study. Jurnal Pendidikan IPA Indonesia, 8(1), 89-100. https://doi.org/10.15294/jpii.v8i1.11647

3. Akben, N. (2019). Suitability of problem scenarios developed by pre-service teacher candidates to problem-based learning approach. Eurasian Journal of Educational Research, 2019(83), 231-252. https://doi.org/10.14689/ejer.2019.83.11

4. Alsabahi, M. A., Maisurah, K., Bahador, K., \& Saat, R. M. (2021). Cogent Business \& Management The influence of personal characteristics and workplace learning on information technology competency among external auditors: The role of organisational culture as a moderator The influence of personal characteristics and wo. Cogent Business \& Management, 8(1). https://doi.org/10.1080/23311975.2021.1899625

5. Amrullah, A., Hadisaputo, S., \& Supardi, K. I. (2017). Pengembangan Modul Chemireligiousa Terintegrasi Pendidikan Karakter Bervisi Sets. Jurnal Inovasi Pendidikan Kimia, 11(1), 1872-1883. 
6. Andriana, E., Syachruroji, A., Alamsyah, T. P., \& Sumirat, F. (2017). Natural science Big Book with Baduy local wisdom base media development for elementary school. Jurnal Pendidikan IPA Indonesia, 6(1), 76-80. https://doi.org/10.15294/jpii.v6i1.8674

7. Astuti, L. I. N. S. (2017). Penguasaan Konsep IPA Ditinjau Dari Konsep Diri. Formatif: Jurnal Ilmiah Pendidikan MIPA, 7(1), 40-48.

8. Awalia, I., Pamungkas, A. S., \& Alamsyah, T. P. (2019). Pengembangan Media Pembelajaran Animasi Powtoon pada Mata Pelajaran Matematika di Kelas IV SD. Kreano, Jurnal Matematika Kreatif-Inovatif, 10(1), 49-56. https://doi.org/10.15294/kreano.v10i1.18534

9. Buldur, A., \& Omeroglu, E. (2018). An Examination of the Relationship between Preschool Children's and Their Teachers' Attitudes and Awareness towards the Environment. Journal of Education and Learning, 7(2), 221. https://doi.org/10.5539/jel.v7n2p221

10. Chetty, N. D. S., Handayani, L., Sahabudin, N. A., Ali, Z., Hamzah, N., Rahman, N. S. A., \& Kasim, S. (2019). Learning styles and teaching styles determine students' academic performances. International Journal of Evaluation and Research in Education, 8(4), 610-615. https://doi.org/10.11591/ijere.v8i3. 20345

11. Creswell, J. W. (2012). Educational Research. University of Nebraska.

12. Darmaji, D., Kurniawan, D. A., \& Irdianti, I. (2019). Physics education students' science process skills. International Journal of Evaluation and Research in Education, 8(2), 293-298. https://doi.org/10.11591/ijere.v8i2.28646

13. Denny, Y. R., Utami, I. S., Rohanah, S., \& Muliyati, D. (2020). The Development of Blended Learning Model using Edmodo to Train Student Critical Thinking Skills on Impulse-Momentum Topic. Jurnal Penelitian \& Pengembangan Pendidikan Fisika, 6(1), 113-120. https://doi.org/10.21009/1.06113

14. Dierks, P. O., Höffler, T. N., Blankenburg, J. S., Peters, H., \& Parchmann, I. (2016). Interest in science: a RIASEC-based analysis of students' interests. International Journal of Science Education, 38(2), 238-258. https://doi.org/10.1080/09500693.2016.1138337

15. Ellegaard, M., Damsgaard, L., Bruun, J., \& Johannsen, B. F. (2018). Patterns in the form of formative feedback and student response. Assessment and Evaluation in Higher Education, 43(5), 727-744. https://doi.org/10.1080/02602938.2017.1403564

16. Endayani, H., Satul, A., Abdul, I., Suratno, Belajar, H., Siswa, P., Negeri, S. D. M. P., Madiun, K., Contoh, B., Issa, J., Tabares, I., Objek, P. B. B., Hasil, L., Informasi, T., Aradea, Ade Yuliana, H. H., Pattiserlihun, A., Setiawan, A., Trihandaru, S., Fisika, P. S., ... García Reyes, L. E. (2017). Model evaluasi kinerja dosen: pengembangan instrumen untuk mengevaluasi kinerja dosen. Jurnal Penelitian Dan Evaluasi Pendidikan, 21(2), 2062014. https://journal.uny.ac.id/index.php/jpep/article/view/16626

17. Fauzan, M., Gani, A., \& Syukri, M. (2017). Penerapan Model Problem Based Learning Pada Pembelajaran Materi Sistem Tata Surya Untuk Meningkatkan Hasil Belajar Siswa. Jurnal Pendidikan Sains Indonesia (Indonesian Journal of Science Education), 5(1), 27-35.

18. Febriyanti, C., Prasetya, R., \& Irawan, A. (2018). Etnomatematika Pada Permainan Tradisional Engklek Dan Gasing Khas Kebudayaan Sunda. Barekeng: Jurnal Ilmu Matematika Dan Terapan, 12(1), 1. https://doi.org/10.30598/vol12iss1pp1-6ar358

19. Firdaus, A., Nisa, L. C., \& Nadhifah, N. (2019). Kemampuan Berpikir Kritis Siswa pada Materi Barisan dan Deret Berdasarkan Gaya Berpikir. Kreano, Jurnal Matematika Kreatif-Inovatif, 10(1), 68-77. https://doi.org/10.15294/kreano.v10i1.17822

20. Greer, L., \& Heaney, P. J. (2004). Real-time analysis of student comprehension: An assessment of electronic student response technology in an introductory earth science course. Journal of Geoscience Education, 52(4), 345-357. https://doi.org/10.5408/1089-9995-52.4.345

21. Hartini, S., Firdausi, S., Misbah, \& Sulaeman, N. F. (2018). The development of physics teaching materials based on local wisdom to train Saraba Kawa characters. Jurnal 
Pendidikan IPA Indonesia, 7(2), 130-137. https://doi.org/10.15294/jpii.v7i2.14249

22. Hetrion, B. D. ., Hetarion, Y., \& Makaruku, V. (2020). Jurnal Teknologi Pendidikan Implementasi Pendidikan Karakter Berbasis Kearifan. Jurnal Teknologi Pendidikan, 22(1), 1-12.

23. Hidayati, N. A., Hendriati, N., Prasetyo, P., Putri, H. A., \& Maimunah, S. (2017). Pengembangan Inovasi Pembelajaran Berbasis Proyek Ilmiah dalam Meningkatkan Sikap terhadap Ilmu Pengetahuan Siswa SMP Kota Malang. Jurnal Konseling Dan Pendidikan, 5(2), 85. https://doi.org/10.29210/116600

24. Ivanov, I. D. (2019). The Use of Interactive Student Response Software in an Introductory International Relations Course. Journal of Political Science Education, O(0), 1-18. https://doi.org/10.1080/15512169.2019.1694533

25. Karlson, K. B. (2019). Expectation Formation for All? Group Differences in Student Response to Signals about Academic Performance. Sociological Quarterly, 60(4), 716737. https://doi.org/10.1080/00380253.2019.1580549

26. Kazu, İ. Y., \& İş, A. (2018). An Investigation About Actualization Levels of Learning Outcomes in Early Childhood Curriculum. Journal of Education and Training Studies, 6(3), 66. https://doi.org/10.11114/jets.v6i3.2928

27. Kosim, M. (2020). Penguatan Pendidikan Karakter di Era Industri 4.0: Optimalisasi Pendidikan Agama Islam di Sekolah. TADRIS: Jurnal Pendidikan Islam, 15(1), 88. https://doi.org/10.19105/tjpi.v15i1.2416

28. Kurniawan, D. A., Astalini, A., Darmaji, D., \& Melsayanti, R. (2019). Students' attitude towards natural sciences. International Journal of Evaluation and Research in Education, 8(3), 455-460. https://doi.org/10.11591/ijere.v8i3.16395

29. Kusuma, F. W., \& Aisyah, M. N. (2012). Implementasi Model Pembelajaran Kooperatif Tipe Think Pair Share Untuk Meningkatkan Aktivitas Belajar Akuntansi Siswa Kelas Xi Ips 1 Sma Negeri 2 Wonosari Tahun Ajaran 2011/2012. Jurnal Pendidikan Akuntansi Indonesia, 10(2), 43-63. https://doi.org/10.21831/jpai.v10i2.912

30. Labudasari, E., \& Rochmah, E. (2019). Pengaruh gerakan literasi sekolah terhadap karakter mandiri siswa di SDN Kanggraksan Cirebon. Premiere Educandum: Jurnal Pendidikan Dasar Dan Pembelajaran, 9(1), 57. https://doi.org/10.25273/pe.v9i1.4254

31. Lacksana, I. (2017). Kearifan Lokal Permainan Congklak Sebagai Penguatan Karakter Peserta Didik Melalui Layanan Bimbingan Konseling Disekolah. Satya Widya, 33(2), 109-116. https://doi.org/10.24246/j.sw.2017.v33.i2.p109-116

32. Li, Q., Tan, X., \& Wang, L. (2021). Testing for error correlation in partially functional linear regression models. Communications in Statistics - Theory and Methods, 50(3), 747-761. https://doi.org/10.1080/03610926.2019.1642492

33. Lizawati, L., \& Uli, I. (2018). Implementasi nilai pendidikan karakter dalam sastra lisan di IKIP PGRI Pontianak. Premiere Educandum: Jurnal Pendidikan Dasar Dan Pembelajaran, 8(2), 140. https://doi.org/10.25273/pe.v8i2.2911

34. Lucke, T., Dunn, P. K., \& Christie, M. (2017). Activating learning in engineering education using ICT and the concept of 'Flipping the classroom.' European Journal of Engineering Education, 42(1), 45-57. https://doi.org/10.1080/03043797.2016.1201460

35. Maharani, L., Hartono, Y., \& Hiltrimarti, C. (2013). Kemampuan pemahaman konsep siswa pada pembelajaran matematika menggunakan model generative learning di kelas viii smp negeri 6 palembang. Jurnal Pendidikan ..., 7(2), 1-17. https://ejournal.unsri.ac.id/index.php/jpm/article/view/4650

36. Muhardini, S., Rahman, N., Mahsup, M., Sudarwo, R., Anam, K., \& Fujiaturrahman, S. (2020). Pengembangan Media Pembelajaran Box Nusantara untuk Membentuk Kemampuan Memahami Konsep Tematik pada Siswa Sekolah Dasar. Jurnal Kependidikan: Jurnal Hasil Penelitian Dan Kajian Kepustakaan Di Bidang Pendidikan, Pengajaran Dan Pembelajaran, 6(2), 284. https://doi.org/10.33394/jk.v6i2.2612

37. Muir, S., Tirlea, L., Elphinstone, B., \& Huynh, M. (2020). Promoting Classroom Engagement Through the Use of an Online Student Response System: A Mixed 
Methods Analysis. Journal of Statistics Education, 28(1), 25-31. https://doi.org/10.1080/10691898.2020.1730733

38. Muslimin., Indaryanti., \& Susanti, E. (2017). Pembelajaran Matematika Dengan Model Reciprocal Teaching Untuk Melatih Kecakapan. Jurnal Pendidikan Matematika, 11(1), $1-13$.

39. Nataliya, P. (2017). Efektivitas Penggunaan Media Pembelajaran Permainan Tradisional Congklak Untuk Meningkatkan Kemampuan Berhitung Pada Siswa Sekolah Dasar. Jurnal Ilmiah Psikologi Terapan, 03(02), 343-358.

40. Newland, S. A. (2021). Review of Learning Catalytics, An Interactive Student Response Tool. Journal of Political Science Education, 17(1), 159-164. https://doi.org/10.1080/15512169.2019.1651652

41. Ningsi, A. P. (2020). Deskripsi Sikap Siswa Terhadap Pembelajarn IPA di SMPN 1 Muaro Jambi. Ibriez: Jurnal Kependidikan Dasar Islam Berbasis Sains. https://doi.org/10.21154/ibriez.v5i5.84

42. Noto, M. S., Firmasari, S., \& Fatchurrohman, M. (2018). Etnomatematika pada sumur purbakala Desa Kaliwadas Cirebon dan kaitannya dengan pembelajaran matematika di sekolah Ethnomathematics at the sumur purbakala Kaliwadas Village of Cirebon and relationship with mathematics learning in school. Jurnal Riset Pendidikan Matematika, 5(2), 201-210.

43. Nurwahidah, Maryati, S., Nurlaela, W., \& Cahyana. (2021). Permainan Tradisional Sebagai Sarana Mengembangkan Kemampuan Fisik Motorik Anak Usia Dini. PAUD Lectura: Jurnal Pendidikan Anak Usia Dini, 4(02), 49-61. https://doi.org/10.31849/paud-lectura.v4i02.6422

44. Oyedeji, S. O. (2017). The Effects of Students' Motivational Factors on their Attitudes toward Mathematics. International Journal of Evaluation and Research in Education (IJERE), 6(4), 277. https://doi.org/10.11591/ijere.v6i4.10770

45. Psaradakis, Z., \& Vávra, M. (2020). Normality tests for dependent data: large-sample and bootstrap approaches. Communications in Statistics: Simulation and Computation, 49(2), 283-304. https://doi.org/10.1080/03610918.2018.1485941

46. Purwasi, L. A., \& Fitriyana, N. (2019). Pengembangan Lembar Kerja Siswa Berbasis Pendekatan Open-Ended Untuk Melatih Kemampuan Pemecahan Masalah Matematis Siswa SMP. Kreano, Jurnal Matematika Kreatif-Inovatif, 10(1), 18-26. https://doi.org/10.15294/kreano.v10i1.16825

47. Ramdan, A. Y., \& Fauziah, P. Y. (2019). Peran orang tua dan guru dalam mengembangkan nilai-nilai karakter anak usia sekolah dasar. Premiere Educandum: Jurnal Pendidikan Dasar Dan Pembelajaran, 9(2), 100. https://doi.org/10.25273/pe.v9i2.4501

48. Rapih, S., \& Sutaryadi, S. (2018). Perpektif guru sekolah dasar terhadap Higher Order Tinking Skills (HOTS): pemahaman, penerapan dan hambatan. Premiere Educandum : $\begin{array}{lllll}\text { Jurnal Pendidikan Dasar Dan Pembelajaran, } & 78 .\end{array}$ https://doi.org/10.25273/pe.v8i1.2560

49. Rasyid, M. A. (2017). Profil Berpikir Reflektif Siswa SMP dalam Pemecahan Masalah Pecahan Ditinjau dari Perbedaan Gender. Kreano, Jurnal Matematika Kreatif-Inovatif, 8(2), 171-181. https://doi.org/10.15294/kreano.v8i2.9849

50. Rukin. (2019). Penelitian kualitatif. Ahmar cendikia Indonesia.

51. Rusmono, \& Alghazali, M. I. (2019). Pengaruh Media Cerita Bergambar Dan Literasi Membaca Terhadap Hasil Belajar Siswa Sekolah Dasar. JTP - Jurnal Teknologi Pendidikan, 21(3), 269-282. https://doi.org/10.21009/jtp.v21i3.13386

52. Sappaile, N. (2017). Pengaruh Kompetensi Pedagogik, Kompetensi Profesional, dan Sikap Profesi Guru Tehadap Kinerja Penilaian Guru di Sekolah Dasar. Jurnal Teknologi Pendidikan, 19(1), 47-58.

53. Setiawan, A. (2017). Hubungan Self Confidence Dan Anxiety Dengan Prokrastinasi Akademik Pada Siswa Kelas X Ma Darut Taqwa Purwosari Pasuruan. Jurnal Psikologi, 4(2), $\quad$ 71-84. $\quad$ https://jurnal.yudharta.ac.id/v2/index.php/ILMU- 
PSIKOLOGI/article/view/1347

54. Sholihat, F. N., Samsudin, A., \& Nugraha, M. G. (2017). Identifikasi Miskonsepsi dan Penyebab Miskonsepsi Siswa Menggunakan Four-Tier Diagnostic Test Pada SubMateri Fluida Dinamik: Azas Kontinuitas. Jurnal Penelitian \& Pengembangan Pendidikan Fisika, 3(2), 175-180. https://doi.org/10.21009/1.03208

55. Suastra, I. W., Jatmiko, B., Ristiati, N. P., \& Yasmini, L. P. B. (2017). Developing characters based on local wisdom of bali in teaching physics in senior high school. Jurnal Pendidikan IPA Indonesia, 6(2), 306-312. https://doi.org/10.15294/jpii.v6i2.10681

56. Sunarti, S., Sukadari, S., \& Antini, S. (2020). Pengimplementasian Pendidikan Karakter Pada Ekstrakurikuler Seni Tari Nawung Sekar. Jurnal Kependidikan: Penelitian Inovasi Pembelajaran, 4(1), 26-42. https://doi.org/10.21831/jk.v4i1.27694

57. Sunaryo, S. (2017). Hubungan antara Pengetahuan dan Pemahaman Siswa tentang Pencemaran Logam Berat dengan Pembentukan Karakter Siswa dalam Menjaga Keberlangsungan Lingkungan Hidup. Jurnal Penelitian \& Pengembangan Pendidikan Fisika, 3(1), 21. https://doi.org/10.21009/1.03103

58. Supriadi, M., \& Hignasari, L. V. (2019). Pengembangan Media Virtual Reality Pada Muatan Pelajaran IPA Kelas VI Sekolah Dasar. JTP - Jurnal Teknologi Pendidikan, 21(3), 241-255. https://doi.org/10.21009/jtp.v21i3.13025

59. Syahrial, Asrial, Kurniawan, D. A., \& Piyana, S. O. (2019). E-Modul Etnokontruktivisme: Implementasi Pada Kelas V Sekolah Dasar Ditinjau Dari Persepsi, Minat Dan Motivasi. JTP - Jurnal Teknologi Pendidikan, 21(2), 165-177. https://doi.org/10.21009/jtp.v21i2.11030

60. Syam, A. R. (2019). Guru dan Pengembangan Kurikulum Pendidikan Agama Islam di Era Revolusi Industri 4.0. TADRIS: Jurnal Pendidikan Islam, 14(1), 1. https://doi.org/10.19105/tjpi.v14i1.2147

61. Tolley. (2014). Qualitative Methods in Public health: a Field Guide For Applied Research. Willey.

62. Utaminingsih, R., Rahayu, A., \& Andini, D. W. (2018). Pengembangan RPP IPA sekolah dasar berbasis problem-based learning untuk siswa learning disabilities Development of primary school natural science lesson plan based on problem-based learning for learning disabilities students. Jurnal Inovasi Pendidikan IPA, 4(2), 191-202.

63. Voith, L. A., Holmes, M. R., \& Duda-Banwar, J. (2018). Clicking Toward Better Grades: The Use of Student Response Systems in Social Work Education. Journal of Social Work Education, 54(2), 239-249. https://doi.org/10.1080/10437797.2017.1283268

64. Wahyu, Y., Edu, A. L., \& Nardi, M. (2020). Problematika Pemanfaatan Media Pembelajaran IPA di Sekolah Dasar. Jurnal Penelitian Pendidikan IPA, 6(1), 107. https://doi.org/10.29303/jppipa.v6i1.344

65. Wood, A. (2020). Utilizing technology-enhanced learning in geography: testing student response systems in large lectures. Journal of Geography in Higher Education, 44(1), 160-170. https://doi.org/10.1080/03098265.2019.1697653

66. Wulandari, A., Handayani, P., \& Prasetyo, D. R. (2019). Pembelajaran Ilmu Pengetahuan Alam Berbasis EMC (Education Mini Club) sebagai Solusi Menghadapi Tantangan Pendidikan dI Era Revolusi Industri 4.0. Thabiea: Journal of Natural Science Teaching, 2(1), 51. https://doi.org/10.21043/thabiea.v2i1.5498

67. Yuliyani, R., Handayani, S. D., \& Somawati, S. (2017). Peran Efikasi Diri (Self-Efficacy) dan Kemampuan Berpikir Positif terhadap Kemampuan Pemecahan Masalah Matematika. Formatif: Jurnal Ilmiah Pendidikan MIPA, 7(2), 130-143. https://doi.org/10.30998/formatif.v7i2.2228 


\section{PROFILE}

Kamid is a Lecturer at the Faculty of Teacher Training and Education Primary contact for editorial correspondence.

Sofnidar is a Lecturer in Faculty of Teaching and Education

Sabila Eka Septi is a Student in Faculty of Teaching and Education

Yulita Dwi Citra is a Student in Faculty of Teaching and Education 